\title{
On the Way to a Sustainable Energy Policy in Japan and South Korea
}

\author{
Elisabeth Schneeweiss
}

\begin{abstract}
The aim of this paper is to examine the sustainability of Japan's and South Korea's energy policies. For the analysis, categories framed by Holgar Rogall for identifying a sustainable energy policy were used. Using official data from the UN and government authorities of both countries as well as secondary literature, a comparison of international goals and legal norms and an analysis of developments in energy policy since 1990 were conducted. Their results show that Japan and South Korea pursue quite different energy policies. In more than half of the criteria, Japan can be seen as having a sustainable energy policy. The country still has to improve its use of energy sources, as it is too dependent on fossil fuels and thus needs to accelerate the development of renewable energies. South Korea's energy policy, however, cannot yet be classified as sustainable. The government still rejects international commitments regarding climate change, a conclusion that is reflected in development since 1990: greenhouse gases rising at a high speed, coupled with low energy efficiency and dependence on fossil fuels. Despite sharing the same basic conditions, the energy policies of Japan and South Korea differ fundamentally.
\end{abstract}

Keywords: Japan, South Korea, energy policy, sustainability icy in Japan and South Korea." In Vienna Journal of East Asian Studies, Volume 4, eds. Rudiger Frank, Ina Hein, Lukas Pokorny and Agnes Schick-Chen. Vienna: Praesens Verlag, 2013, pp. 159-189. https://doi.org/10.2478/vjeas-2013-0007 


\section{Introduction}

The industrial revolution in the 19th century marked a turning point in the use of energy in human history, as the basic understanding of energy shifted and the use of fossil fuels became widespread. It was only in the second half of the 20th century that men became aware of their wasteful use of exhaustible resources and the ecological damage it had brought with it. Today we stand at the crossroads, and the alternatives are climate and resource wars or a turning towards sustainability. It is the energy policy that each nation designs that bears the responsibility for minimising the lavish use of resources and for fighting anthropogenic climate change (Weizsäcker 2009: 15).

The aim of this paper is to outline the energy policy of two East Asian nations, Japan and South Korea, and to examine if and to what extent there has been an attitude shift towards a more responsible consumption of energy since 1990, the base year of the Kyoto Protocol. The question raised is: Do Japan and South Korea pursue a sustainable energy policy?

To answer this question, the term 'sustainable energy policy' had to be defined first. The theoretical framework is based on Holger Rogall's (2009) definition of sustainable energy policy. In his work Nachhaltige Ökonomie Rogall presents a list of criteria to measure such a sustainable energy policy, which in this paper were employed to analyse the energy policies of Japan and South Korea.

In this paper, a mix of primary and secondary sources is used. The theory, as the abstract above has noted, is based on Holger Rogall's research, and, where possible, official data from Japanese and South Korean government agencies, as well as the International Energy Agency (IEA), the United Nations (UN) and the United Nations Framework Convention on Climate Change (UNFCCC) have been used. In addition, secondary sources on climate and energy policy of both countries have been consulted.

\section{Definition of a sustainable energy policy}

\section{Sustainable energy policy and its objectives}

Energy policy is a subcategory of sectoral adjustment policy and thus part of a nation's economy policy. As it possesses many links to other political sectors, such as social, transport, climate, environmental and even foreign or security policy, it is difficult to differentiate it clearly from those areas (Woyke 2008: 178).

In general, a country's energy policy has three objectives: economic efficiency, security of energy supply, and environmental compatibility. The emphasis each 
government puts on any one of these objectives is different, though, and changes according to each country's current circumstances. Economic efficiency describes the state's attempt to make the energy sector functional, efficient and competitive. At the same time the price for energy consumption should set at such a level that an unjustifiable financial strain on both the economy and society-the collective of private households - can be avoided. Price controls, subventions and regulatory authorities are only some of the many possible attempts to secure the economic efficiency of an energy policy, which also help secure the competitiveness of a country's energy-intensive industries (Laumanns 2005: 279; Rogall 2009: 387).

The second objective, security of energy supply, poses the challenge of guaranteeing the national energy demand in a secure and stable way, and without any interruptions. This objective shows the links between a country's energy policy and its foreign and security policy. An excessive dependence on imported primary energy sources poses a potential threat for the security of energy supply. Most energy imports, which mainly consist of the import of crude oil and gas, are obtained from unstable regions such as the Persian Gulf, or from such countries as Nigeria and Venezuela, and thus cannot be guaranteed at times of crisis (Griffin 2009: 20-21). It is thus vital for a functioning energy policy to minimise this dependence on energy imports so that the chance of bottlenecks in supplies and the threat of being vulnerable to blackmail on the international stage can be reduced (Reiche 2005: 20). Since fossil fuels are still much cheaper than other energy sources, the objective of security of energy supply conflicts with economic efficiency. A sudden abandonment of crude oil and natural gas would not only be very expensive for the consumers, but also curtail the security of energy supply, as in most countries the infrastructure and technology for the use of renewable energies has mostly been neglected in the past (Griffin 2009: 23-26).

The third objective of energy policy is a relatively new one: environmental compatibility. It stands for the attempt to reduce the negative impact that the energy sector, especially the use and transport of fossil fuels, has on environment and climate. This objective also shows that it is hard to separate energy policy from climate and environmental policy: climate change is caused by a rapid rise in greenhouse gases in the atmosphere. The most important of all harmful greenhouse gases is carbon dioxide. Human activity brought about a rise from 280 ppm (parts per million) carbon dioxide in the year 1850 to $379 \mathrm{ppm}$ in 2005, and it is bound to rise even more in the future (Rogall 2009: 382; Töpfer 2005: 5). The greenhouse gas emissions that are generated through the consumption of energy, which includes electricity, transportation, industry, and housing, add up to 65 percent of all atmospheric emissions (Rogall 2009: 282). It is because of this fact that environmental compatibility has gained more and more importance in the energy policy of industrial nations in recent years. 
Rogall defines a sustainable energy policy as one that combines all the aforementioned objectives: energy has to be provided at a feasible price (economic efficiency), its supply has to be secured permanently (security of supply), and the consumption of fossil fuels has to be curtailed so that sustainability can be accomplished in the future (environmental compatibility). A sustainable energy policy is thus based on sustainable development, that is, development that meets the needs of the current generation without taking away the chance of future generation to have the same (Rogall 2009: 38). For a sustainable energy policy this means that for preference non-exhaustible energy sources should be used (Voß 1997: 64-65).

For this paper, the categories stipulated by Rogall to measure whether a nation's energy policy is sustainable were used.

\section{Global operational targets of a sustainable energy policy}

Operational targets on a global scale are mostly based on tactics to fight anthropogenic climate change and reduce its negative impact on the human environment. As the energy sector is responsible for about 65 percent of all global greenhouse gas emissions, strategies to contest climate change are mostly based on changes in energy policy.

The United Nations provide an important platform for discussing the international commitments to climate protection. The first essential agreement was the United Nations Framework Convention on Climate Change of 1992, which was implemented on March 21, 1994 and signed by 192 nations (UN 2007: paragraph 1; Lovett 2005: 94). Its ultimate objective is 'to stabilise greenhouse gas concentrations in the atmosphere at a level that will prevent dangerous human interference with the climate system' (UNFCCC 2011a: article 3). While the UNFCCC's goal is binding under international law, it states no obligatory measures to reach it. Instead it is suggested that appropriate steps should be set in the future, and that co-operation between the industrial nations responsible for the majority of all greenhouse gas emissions is absolutely necessary (UN 1992a: 3-4). While no concrete measures were proposed in the UNFCCC, it can nevertheless be seen as an important cornerstone for international climate protection. It was also the first time that the objective of resisting climate change was formulated on an international agreement (UN 1992b: 83-84).

The UNFCCC was followed by official climate conferences held by the UN, starting in 1995 in Berlin. A breakthrough was achieved at the third conference in 1997 in Kyōto 京都, Japan. On December 11, 1997, the Kyoto Protocol was adopted (UNFCCC 2011b: 4). For the first time in the fight against climate change, obligatory emission targets were determined. The countries listed in Annex I committed themselves to binding targets and three different mechanisms to reach these: emis- 
sion targets and emission trading, the Clean Development Mechanism (CDM), and the Joint Implementation (UNFCCC 2011b, section on the Kyoto Mechanism). The protocol was ratified on February 16, 2005; the 37 Annex I countries vowed to reduce their greenhouse gas emissions in the period 2008 to 2012 by 5.2 percent on average, relative to their annual emissions in the base year of 1990 (IPCC 2011: paragraph 2; IPCC 2000: 51-52).

In addition to the UNFCCC and the Kyoto Protocol, long-term targets also exist. At the 35th G8 summit in L'Aquila in Italy in 2009, the industrial nations committed themselves to reducing their emissions by 80 percent by the year 2050 , relative to the base year 1990 (Kikkawa 2010: 1).

Apart from these targets, the limitation of carbon dioxide concentration in the atmosphere is also a global operational target. In 1997, the Intergovernmental Panel on Climate Change (IPCC) claimed that carbon dioxide concentration should be stabilised at between 350 and $750 \mathrm{ppm}$ to limit the global rise in temperature. Newer data suggest, however, that this concentration must not go above $440 \mathrm{ppm}$, if a rise of more than two degrees Celsius - which would cause a dangerous disturbance of the climate system — is to be prevented (UN 1992a: 5; IPCC 1997: 8; Umweltbundesamt 2011: Bedeutung).

Next to the secure supply of energy for a reasonable price for the world population, it is these conventions and limits that constitute the global operational targets.

\section{International legal norms for a sustainable energy policy}

International legal norms for a sustainable energy policy are closely connected to global operation targets, as they are necessary for the implementation of these objectives. This paper will not only make an analysis of whether Japan and South Korea have agreed to international legal norms, it will also look at their national laws to see whether they conflict with their international counterparts. Similarly to global operational targets, international legal norms concerning energy policy focus predominantly on the fight against climate change (Töpfer 2005: 5).

Currently, only two agreements concerning climate protection exist that are binding under international law. While scientists were already alluding to the dangers of climate change caused by human activities at the end of the 1970s, the first legally binding agreement was only designed and implanted in 1992: the UNFCCC (Lexikon der Nachhaltigkeit 2011: paragraphs 1-3). Since it poses no binding targets for stabilising greenhouse gas emissions, it also lacks a functioning sanctions mechanism for countries that do not actively work on protecting the climate, which in turn actively limits the convention's efficiency (Böhringer and Vogt 2003: 477).

In the second agreement, the Kyoto Protocol that was enacted in 1997, binding reduction targets for its 37 participating Annex I countries were determined. The 
Kyoto Protocol is said to be a milestone in international climate protection, yet it possesses several shortcomings: the main point of criticism is that developing and emerging countries are exempt from any reduction commitments. Furthermore, the $\mathrm{CDM}$ - the only one of the Kyoto Protocol's three mechanisms that includes these nations in combatting climate change-is in great need of improvement (Grubb, Vrolijk and Brack 1999: 136; Rogall 2009: 395).

Another major critique is the insufficient mechanism for sanctions where a country fails to meet its targets. At the seventh Conference of the Parties (COP) in Marrakech in Morocco in 2007, the participants in the Kyoto Protocol agreed on a sanctions mechanism that works through two parallel institutions: on one hand, it set up a Facilitative Branch, with the duty of advising the participating nations on how to reach their binding reduction targets; on the other hand, an Enforcement Branch was implemented and tasked with deciding whether or not a country has failed to meet its targets (UNFCCC 2011c: paragraph 2). While the Enforcement Branch has a variety of possible sanctions at its disposal, critics like Cathrine Hagem and her colleagues point out the difficulty in actually assessing a country's failure. In addition to that, they denounce the lack of willingness to hold violating parties responsible, a timidity that stems from the other parties' fear of harming themselves, since such sanctions would raise prices for reduction certificates or fossil fuels. Such critics also claim that the members of the Executive Branch care more about their respective countries' interests than the realisation of the Kyoto Protocol targets and that this curtails its efficiency (Hagem et al. 2005: 2112-2121).

\section{Global developments in energy policy since 1990}

Rogall calls the third category he uses to define a sustainable energy policy 'Chances to reach the operation targets' (Rogall 2008: 19; 2009: 404). So as not to give the impression that this point for analysis deals with speculations about the future, it was changed in this paper to depict its actual function: to show the actual developments in Japan's and South Korea's energy policies since the base year of 1990, and to pronounce on whether a trend towards a greater sustainability can be attested.

\section{Development of greenhouse gas emissions}

Emissions of global greenhouse gases saw an increase from 6.1 billion tons in 1992 to 8.5 billion tons in 2007, i.e. a 38 percent rise (Green Car Congress 2008: paragraph 1). Those responsible for that sharp rise were the United States and the People's Republic of China, whose emissions increased in that 15 -year period by 20 percent and 260 percent respectively. By 2007, China was the biggest global emitter 
of greenhouse gases with an annual share of 22.3 percent of global emissions (Rogall 2009: 406; Green Car Congress 2008: paragraph 3).

2008 can be seen as a turning point, as in that year countries other than the Annex I parties caused more emissions of greenhouse gases for the first time - around 40 percent (IEA 2010a: 7; 2010b: 45). Global emissions continued to rise at an extreme rate until 2010, constituting the sharpest increase in history, by 1.6 gigatonnes of carbon dioxide, an increase of 5 percent relative to 2008, caused mostly by developing countries (Spiegel Online 2011: paragraph 2.9). On a global scale a reduction of greenhouse gas emissions has not yet been achieved.

\section{Developments in energy efficiency}

Energy efficiency describes the supply of energy services and products with a minimum of energy use. It measures the utilisation of the energy deployed (Laumans 2005: 191). Not only can ecological and health costs be reduced with the implementation of energy-efficient products and services, the latter also help to reduce greenhouse gas emissions, with, in turn, positive repercussions on the import of fossil fuels - and thus enhance the security of energy supply, and sustainability (BMWFJ 2011: paragraphs 1-5). The sharp increase in import costs for fossil fuels and the increased attention that governments pay to climate protection caused a decrease in global energy intensity (energy intensity = energy input/GDP) by 1.6 percent yearly between 1990 and 2006 (World Energy Council 2008: 1). To improve a nation's energy efficiency, the UN suggests concentrating on national industries, the transportation and energy sectors, and agriculture. Furthermore, innovations in the energy transportation sector are vital, as both the production of primary energy sources as well as the generation of electricity still have low degrees of efficiency (Ferrari 2008: 173; Laumanns 2005: 194-195).

\section{Use of energy sources}

The use of primary energy sources is of special interest for achieving a sustainable energy policy. These sources can be divided into three groups: fossil fuels, including oil, natural gas, and coal; nuclear power sources like uranium and plutonium; and renewable energy sources like solar energy, hydraulic power, or energy generated from wind (Reiche 2005: 57). Despite efforts to reduce the use of fossil fuels ever since the implementation of the UNFCCC, they still accounted for 86 percent of all primary energy sources consumed in 2007. Nuclear energy sources had a share of 8 percent in the global energy mix, while all renewable energy sources combined accounted for only 6 percent (Griffin 2009: 25). 
The exhaustibility of fossil fuels as well as the fact that they are especially damaging to the climate, as they generate most of the harmful greenhouse gas emissions, make it necessary to invest in renewable energy sources that also pose less danger than nuclear power sources (Voß, Fahl and Schaumann 1997: 392-393).

\section{Sufficiency strategies}

Sufficiency describes both a change in one's lifestyle and conscious energy-saving measures. Abandonment of excessive consumption as well as an economical use of energy both in private households and in industry fall into the area of sufficiency. In industrial nations, however, sufficiency strategies are hardly used, as governments lack the courage to request resource management and economisation in people's daily lives (Rogall 2008: 36; Winterfeld 2007: 51).

\section{Analysis of Japan's and South Korea's energy policies}

\section{Japan's energy policy}

As only few natural resources can be found on Japanese soil, the country relies heavily on energy imports to satisfy its demands (Umbach 2006: 42). Until the 1980s it was mainly the consumption of oil from the Middle East that secured Japan's energy supply. Suffering economic setbacks caused by the first oil crisis in 1973, when imported oil accounted for 75 percent of all primary energy sources consumed, the Japanese government was already starting to work towards a diversified and more stable, and thus sustainable, energy policy in the 1970s (Morse 1981: $3)$.

\section{Operational targets of Japanese energy policy}

While Japan has a leading role in climate protection negotiation today, it was one of the last countries to join the international discourse at the end of the 1980s. In the beginning, the Japanese government aligned itself with the United States to secure its economic needs. It was only in 1997, at the third COP, which was hosted in Kyōto, that Japanese politicians recognised the benefits of playing an active role in protecting the climate (Kameyama 2003: 137-146).

Japan has signed the UNFCCC and is also one of the Annex I parties of the Kyoto Protocol. It was the latter that marked a new phase of climate policy in Japan, as the government actively started promoting innovations and successor agreements 
on both the national and the international stage. In 2003 at the ninth COP in Italy the Japanese delegation emphasised the importance of the Kyoto Protocol in its speech:

\begin{abstract}
[The] Kyoto Protocol is a significant first step toward strengthening actions against climate change. It is the only viable formula that we have so far found. ...Japan strongly urges the countries that have not yet concluded the Protocol to do so as soon as possible. Finally, we must also begin to discuss the future actions to address climate change and identify their requirements in medium and long-term perspective. ...In this regard, the Government of Japan wants to stress the importance of establishing a set of common rules which are applied to all the countries (MOFA 2003: paragraphs 6-7).
\end{abstract}

The Japanese government has maintained this stance at every succeeding conference ever since. In 2007, the former prime minister Abe Shinzō 安倍晋三 (b. 1954) also set out the 'Cool Earth 50' plan that outlined his government's intention to halve the country's emissions by 2050 relative to 1990, and proposed that this target be applied globally (Prime Minister of Japan and His Cabinet 2007: Proposal 1: LongTerm Strategy). In the Copenhagen Accord of the 15th COP in 2009, the Japanese government also accepted the goal to reduce emissions by 25 percent by 2020 . Since this aim is not legally binding, it can be seen as an international operational target (MOFA 2010: paragraph 2).

Three main players are responsible for formulating the Japanese operational targets. The Ministry of Foreign Affairs (MOFA) represents the country's interests at international conferences. It is made up of 16 departments, of which one is the International Cooperation Bureau with its special Climate Change Divisions, which deals with climate protection on the international stage. Apart from that, the ministry has access to more than 50 percent of Japan's Official Development Assistance budget (MOFA 2009: Organization and Function; Asuka-Zhang 2003: 155-156). The second player is the Ministry of the Environment (MOE), which operates both nationally and internationally to promote a sustainable society through co-operation with other countries (MOE Japan 2011: Aiming at the Establishment of a New Society, Keywords of the Policy Measures). The Ministry of Economy, Trade and Industry (METI) is the third protagonist and responsible for formulating Japan's industry and energy policy (Asuka-Zhang 2003: 157). Before the implementation of the Kyoto Protocol it maintained the stance that the economy must not be weakened by climate protection measures. Nowadays the ministry promotes the use of renewable energy sources and the development of new technologies to join economic growth with sustainability (METI 2010a: 7-16).

After implementing the Fundamental Law on Energy Policy Measures in 2002, the first energy plan of Japan's post-war history was presented in 2003: the Basic Energy Plan. It was revised in 2010 and renamed the New Basic Energy Plan. Its main operational targets up to 2030 are: strengthening the security of the energy supply, the expansion of policies to combat climate change, economic growth with 
the energy sector as a driving force, the restructuring of energy policy, and a further opening of the energy markets and more awareness among the population (Duffield and Woodall 2011: 3741-3743). (For further discussion of the plan, see the following section.)

On the basis of the Basic Energy Plan, it can be reasoned that the Ministry of Economy, Trade and Industry has understood the compatibility of the three main objectives of a sustainable energy policy. Its national operation targets comply with those formulated by the UN, since all are centred around the reduction of greenhouse gases and the development of sustainable energy technologies.

\section{Legal norms of Japanese energy policy}

As an industrial nation and member of the UNFCCC, Japan committed itself to meeting binding reduction targets designed for the Annex I parties to resist anthropogenic climate change. The government vowed to reduce its greenhouse gas emissions by six percent relative to the base year of 1990 within the first period of validity (MOE Japan 2008: 1).

It was in 1990 that the importance of reducing the emission of greenhouse gases and other substances harmful to the climate was formally acknowledged for the first time in Japan in the Action Program to Arrest Global Warming, albeit without defined reduction targets (MOE 2008: 5). After the Kyoto Protocol was enacted, the Japanese government established the Global Warming Prevention Headquarters. This agency worked out the Guideline for Measures to Prevent Global Warming in the same year, a framework for combining the targets of a sustainable energy policy, the security of energy supply, and sustainability, while simultaneously ensuring economic growth (Prime Minister of Japan and His Cabinet 2002: paragraphs 19).The guideline acknowledges the role that innovations in the energy sector, i.e. energy-saving measures and development of new energy sources (including nuclear energy), play in reaching its commitments. Furthermore, in 2005, the Kyoto Protocol Target Achievement Plan, which laid out a scheme for reaching the country's reduction targets, was published. It combines both the Action Programme of 1990, as well as other guidelines like the Basic Policy on Measures to Tackle Global Warming from 1999 (Japan Environmental Quarterly 1998: 1; MOE Japan 2008: 5). The Japanese Ministry of the Environment described the role of the plan as such:

[T] he Government has tried to incorporate in this Plan a variety of measures and policies leading to the realization of a low-carbon society that can simultaneously achieve both feeling of affluence in life and greenhouse gas emissions reductions, with the viewpoints both on steady achievement of the immediate target of the Kyoto Protocol commitment and on approaches to take after the first commitment period toward the achievement of long-term, continuous emissions reductions (MOE Japan 2008: 94). 
The foregoing shows that the Japanese government is not only actively working on achieving its own reduction targets, but also encourages the formulation of another legally binding international treaty to fight climate change. The 'Cool Earth 50' Plan (see the section above on 'Operational targets of Japanese energy policy') is another attempt to sway the international community to work out long-term reduction targets (Prime Minister of Japan and His Cabinet 2007: Proposal 1: Long-Term Strategy).

Concerning its energy policy, Japan lacked a comprehensive energy strategy for much of its post-war period. From 1967, the Japanese government started publishing the Long-Term Energy Supply Strategy and Demand Outlook every two to five years. These outlooks were focused on major indices such as expected energy consumption per sector and, by the end of the 1980s, the presumed output of carbon dioxide as well. However, specific guidelines concerning energy policy were not provided (Duffield and Woodall 2011: 3741). It took the Japanese government until 2003 to work out a systematic and comprehensive energy strategy, which is known as the Basic Energy Plan. This plan was based on the Fundamental Law on Energy Policy Measures adopted in 2002, better known as the Basic Act on Energy Policy, which called for devising comprehensive long-term energy strategies to ensure the energy supply in such a way that economic growth and the protection of the environment at both national and global levels could be guaranteed (Duffield and Woodall 2011: 3742; METI 2010b: Background). The Basic Energy Plan has to be reviewed every three years and be amended if necessary. This has already happened twice, in 2007 and 2010. The second revision brought the most fundamental changes so far. The main addition was that a restructuring of the energy industry should be pursued in order to achieve both national and international operation targets. In order to create an independent and environmentally friendly energy supply structure, the government is pursuing four goals: the development and promotion of renewable energy, the further promotion of nuclear power, more efficient technologies for the use of fossil fuels, and the further development of supply structures for electricity and gas. Apart from those main goals, the government also strives to achieve further improvements and innovations in the housing and transportation sector (METI 2010a: 4-5).

In the revised Basic Energy Plan of 2010, sustainability and climate protection are given as equal importance as security of energy supply, in contrast to its previous versions and the New National Energy Strategy published in 2006, ${ }^{1}$ which focused on ensuring a secure supply for energy. The goal of reaching a 'low emission society' shows especially that the energy plan is compatible with the UNFCCC and the Kyoto Protocol. The only uncertainty is whether the government will be able to achieve its ambitious targets with its current laws and measures (Duffield and Woodall 2011: 3746).

1 See Ministry of Economy, Trade and Industry 2006: 10. 
Developments in Japanese energy policy since 1990

\section{Japan's greenhouse gas emissions}

As an Annex I party to the Kyoto Protocol, Japan vowed to reduce its greenhouse gas emissions by 6 percent in the first period of validity from 2008 to 2012, relative to the base year 1990 (see the section above on 'Legal norms of Japanese energy policy'). In that year the country generated 1,268 million tons of carbon dioxide equivalent (CDE), of which 90.13 percent was caused by carbon dioxide emissions; this figure positioned Japan as the sixth biggest emitter in the world. This did not change until 2007 (Covering Copenhagen 2011: Historical and Projected Data).

Despite several commitments by the government to curtail its emissions and the desired development of nuclear energy, Japan's greenhouse gas emissions nevertheless grew significantly until reaching a temporary peak in 2007: the country saw a rise in emissions of 8.5 percent relative to 1990 to a total of 1,400 million tons $\mathrm{CDE}$ - which meant a divergence of 14.5 percent from its reduction targets (UNFCCC 2011d: 1).

The industrial sector, which was still primarily responsible for the country's emissions, managed to reduce its share by 3.2 percent in that period, from 482 million tons CDE to 466 million tons CDE (Lau et al. 2009: 4775). This decline can be attributed both to an improved energy efficiency and to the Voluntary Action Plan devised by the Japanese Business Federation (Nihon keizaidantairengōkai 日本経済 団体連合会). This plan encourages the implementation of voluntary, not legally binding, reduction targets by the federation's members to stabilise and reduce their carbon dioxide emissions (Kiko Network 2007: Summary). All the other sectors saw an increase in greenhouse gas emissions, most of all the transport, housing, and commercial sectors, whose emissions rose by 16.7 percent, 30 percent and 39.5 percent respectively until 2005 (UNFCCC 2011d: 2).

After 2007, Japan's emissions saw a decrease of 6.4 percent to 1,282 million tons CDE in 2008 (National Institute for Environmental Studies 2010a: 3; UNFCCC 2011d: 1). The decline was brought on by the economic recession Japan fell into when the country was hit by the global financial crisis in the same year. According to preliminary calculations by the National Institute for Environmental Studies, the downward trend of emissions also continued in 2009. To reach not only its Kyoto Protocol targets but also its ambitious long-term reduction goals, the Japanese government will need to take additional steps, as its current measures seem insufficient (National Institute for Environmental Studies 2010b: 1-3). 


\section{Japan's energy efficiency}

It was at the end of the 1970s that the Japanese government acknowledged the opportunities that resulted from an improved energy efficiency. In 1979, the Energy Conservation Act, also known as the Law Concerning the Rational Use of Energy, was enacted. Its aim was to monitor and diversify consumption in four sectors: industry, transportation, construction, and engineering (Shiel, Jeffers and Dyar 2011: 7). The law underwent six revisions up to 2008 and is regarded as a pillar of Japanese energy policy (ECCJ 2011: Chronicles of Energy Conservation Laws). After the implementation of the Energy Conservation Act, Japanese energy efficiency had improved by 37 percent by 2002, making Japan the most energy-efficient country in the world (Nishimura and Giri 2008: 5). While, in the beginning, the law focused on reducing the dependence on imports through reducing the consumption of primary energy sources, its goal was changed in 1992, after the signing of the UNFCCC, 'to meet the economic and social environment of energy at home and abroad' (ECCJ 2011: Amendment of 1993).

An important change was also brought on by the Top Runner Program, which was enacted in 1998. The programme seeks to achieve the best energy efficiency standards for a variety of 21 products. Kodaka Atsushi from the METI described its mechanism:

The product on the market with the highest energy efficiency (the Top Runner) sets the standard. The Top Runner Program triggers the race for the top among manufacturers. The necessity of meeting the Top Runner Program provided the companies with an incentive to utilize the technologies, which they may otherwise have waited to commercialize (Kodaka 2008: 4).

Furthermore, the Energy Efficient Retailer Assessement System of 2003 makes it easier for consumers to check on a product's energy consumption, which in turn encourages manufacturers to improve their commodities further (Kodaka 2008: 5; Akahoshi 2008: 51-52). Both programmes have been a great success in Japan, as they improved the energy efficiency of all 21 product classes.

While the Energy Conservation Act has brought energy efficiency improvements in the industrial sector, the transportation and private housing sectors still need further regulations to optimise energy efficiency and curtail the growing energy consumption rate (Akahoshi 2008: 39-43, 53).

\section{Japan's use of energy sources}

Japan is a country with few resources on its territory, a circumstance that compelled the government, after being hit hard by the first oil crisis in 1973, to start working on diversifying its energy mix in order to stabilise the security of energy supply. In 
May 1980, the Law Concerning the Promotion of Development and Introduction of Alternative Energy, which built the foundation for Japan's efforts to develop new energies instead of oil, was passed (Shin 1986: 8, 51). This law also saw the establishment of the New Energy and Industrial Technology Development Organization, which in its early years mainly promoted the development and promotion of nuclear energy, coal, and hydropower (Shin 1986: 51; METI 2010a: 9).

In 1993 the New Sunshine Project was established through combining the Sunshine Project and the Moonshine project with the goal of developing both advance technologies for the consumption of fossil fuels and renewable energies to reduce greenhouse gas emissions (Krupp 1997: 249).

Despite these efforts, Japan stayed dependent on fossil fuels throughout the 1980s. In 1990, fossil fuels generated 84 percent of the country's total energy mix, whereas nuclear energy and renewable energies were responsible for only 9 percent and 7 percent respectively. While the share of oil in the energy mix dropped to 52 percent in 1990 and further to 44 percent in 2007, coal and natural gas saw a sharp increase to 16 percent and 21 percent respectively (METI 2010a: 9).

In 2008, nuclear energy was responsible for 13.6 percent of all primary energy, and around 30 percent of all electricity generated in Japan (Umbach 2006: 45; World Nuclear Association 2011: paragraph 3). The Japanese government emphasised the importance of nuclear energy for the country's self-sufficiency rate and had planned to raise the share of nuclear energy by 1.8 percent per year, until revising plans in 2004 (World Nuclear Association 2011: Recent energy policy: Focus on nuclear; Umbach 2006: 47-48). After the Fukushima Daiichi nuclear disaster (Fukushima daiichi genshiryokuhatsuden shojiko 福島第一原子力発電所事故) in March 2011, however, the future of Japan's nuclear industry is still unsure.

Renewable energies still play a subordinate role in Japan despite all efforts of the government to promote them, e.g. with the Renewable Portfolio Standard system (a regulation that requires energy suppliers to obtain a certain amount of energy from renewable sources) of 2003. In 2008, only 3.4 percent of the energy mix was generated by renewable energies. Hydropower was responsible for 1.3 percent, solar, wind and geothermal energy combined for 0.7 percent, and waste combustion and biomass the remaining 1.4 percent (IEA 2010c: Share of total primary energy supply in 2008). In 2009, the Ministry of Economy, Trade and Industry adopted the Bill on the Promotion of the Use of Nonfossil Energy Sources and Effective Use of Fossil Energy Materials by Energy Suppliers, and the Bill to Amend the Act on the Promotion of the Development and Introduction of Alternative Energy in order to raise the share of renewable energy on the energy mix to 9 percent by 2020 (APEC Energy Working Group 2009: 1-2; New and Renewable Energy Division, Agency for Natural Resources and Energy: 2). 


\section{The Japanese government's sufficiency strategies}

Sufficiency strategies also play a subordinate role in Japan's energy policy, as it is difficult to convince an industrial nation's population to abstain from consumption. Nevertheless, the country's government has enacted programmes that encourage energy saving. In 2005, the Ministry of the Environment announced the Cool Biz campaign. The goal of the programme was to convince offices, and the public as a whole, to refrain from cooling their rooms to below 28 degrees Celsius, and to make employees come to work without a jacket and tie so that they would sweat less. Because of wide participation in the campaign, it was extended to the following years as well (MOE Japan 2005: paragraphs 1-3).

The search to reduce stand-by consumption in the private sector also falls into this category, since it is responsible for nearly 7 percent of all electricity consumed per household (Akahoshi 2008: 35). Uniform Energy-Saving Labels in combination with the products of the Top Runner Program (see section above on 'Japan's energy efficiency') provide consumers with information and incentives to buy energyefficient commodities that help them save money and reduce their stand-by rate (Ohkuni 2008:4; Akahoshi 2008: 52).

While sufficiency strategies are not the main priority of Japan's energy policy, the government does utilise the options it is given to encourage the public and private sectors to save energy.

\section{South Korea's energy policy}

Similarly to Japan, South Korea lacks natural resources that might make it independent of fossil fuel imports and thus secure the country's energy supply. It is because of this that the government pays particular attention to the second goal of a sustainable energy policy: security of energy supply (Kim 2006: 61-61). The only primary energy source in South Korean soil is anthracite coal, which was widely used, after firewood, until the 1960s. The rapid economic development that commenced in the following decade propelled energy consumption into growing at a furious pace, but also increased dependence on fossil oil imported from the Middle East (Shin 1986: 2-3). Despite having been hit less hard than many industrial nations by the first oil crisis in 1973, the Korean government nevertheless started devising plans to diversify energy sources and import regions to ensure security of energy supply (Kim 2006: 70; Shin 1986: 5-6). 


\section{Operational targets for South Korean energy policy}

On June 13 1992, South Korea signed the UNFCCC, which came into effect for the country on March 21, 1994 (UNFCCC 2011e: paragraph 10). The official delegation accepted the Kyoto Protocol on November 8, 2002 (Choi 2009: 5). As a developing nation, the South Korean government refused to agree to binding reduction targets, fearing negative consequences for the country's economic development (Jung 1996: 258). Next to Mexico, South Korea is the only member of the Organisation for Economic Co-operation and Development (OECD) that has not yet entered into a commitment concerning global climate protection (Stavins 2010: paragraph 4).

Until the 1990s, South Korean energy policy thus focused mainly on reducing dependence on imported fossil fuels, which were used for the most part by the energy-intensive industrial sector, itself necessary for economic development (Kim 2006: 65-67). It was in 1998 that the climate policy of South Korea was formulated for the first time, after the Asian financial crisis had hit the country hard in the year before. In April 1998, the Climate Change Committee was founded, with the role of devising national action plans for the UNFCCC. Four such plans had been adopted by 2011: the first covered 1999 to 2001, the second 2002 to 2004, the third 2005 to 2007. They mainly dealt with measures for the implementation of the UNFCCC, improving energy efficiency and raising the population's awareness of climate protection; the third plan also stated that the government should assume an active role in international negotiations (Oh 2008: 488; Yoo 2008: 9-10). The fourth National Action Plan, adopted in 2008, marked a turning point in South Korean climate policy. It also introduced the new national motto, 'Low Carbon, Green Growth' (Jung and Ahn 2010: 3). For the first time environmental compatibility and economic development are seen as able to co-exist, while sustainability should be used to further, not hinder, growth (Presidential Committee on Green Growth 2011: National Strategy).

As with Japan, three main parties are responsible for South Korea's energy and climate policy. The Ministry of Foreign Affairs and Trade (MOFAT) is not only responsible for foreign and trade policy, but also acts as a representative at international negotiations (MOFAT 2011a: History). It was this ministry that achieved classification as a developing nation without any binding reduction targets. Ever since revising the government's opinion on climate change in 2008, MOFAT has also started promoting co-operation in energy and resource management on a global scale (MOFAT 2011b: Key Diplomatic Tasks; Kim 2002: 51). The Ministry of Environment (MOE), as a second player, is responsible for environmental protection and educating the general public about a sustainable and energy-saving lifestyle (MOE ROK 2011: Overview). The most important party in South Korea's energy policy is the Ministry of Knowledge Economy (MKE), as it is responsible for devising and implementing the country's energy policy. In its five-year plans of the past it 
stated that its most important goal was the security of energy supply to further economic development (Shin 1986: 4-5). While this objective is still seen as crucial, sustainability is no longer seen as detrimental. On the contrary, 'Low Carbon, Green Growth' even seeks to advance development by progressing and promoting new energy sources and technologies that are environmentally compatible (MKE 2011: paragraph 1).

While South Korea's stance on climate change was quite reserved despite having signed both the UNFCCC and the Kyoto Protocol, the government began to rethink its position after the Asian financial crisis. Now, economic development and a sustainable energy policy are seen as consistent with each other, in a move illustrating a slow convergence of international and South Korea's national operation targets.

\section{Legal norms of South Korea's energy policy}

Despite its economic catching-up process ever since the 1960s, South Korea is still classified as a developing nation. This categorisation means that the country, as a non-Annex I party of the Kyoto Protocol, is not bound by any compulsory reduction targets. However, it appears as one of the leading forces in the Clean Development Mechanism, which calls for support from industrial nations for developing countries. South Korea, having more than 50 such projects registered and permitted in the beginning of 2011, aims to expand the market for CDM certificates (IEA 2006: 55; Climate Connect 2011:2).

Up to the middle of the 1990s, South Korea positioned itself with the People's Republic of China and India in climate policy matters, emphasising the historical responsibility industrial nations had to bear in the fight against climate change. Thus the government rejected any binding targets and active participation. The first changes occurred in 1998 with the implementation of the Committee on UNFCCC, when the country began compiling nation communications for the UN concerning energy policy. For the first time, the South Korean government also expressed willingness to accept binding reduction targets for the third period of validity from 2018 to 2022 (Kim 2002: 51-59).

This dismissive stance led South Korea's energy policy of the 1970s and 1980s to focus mainly on energy savings, the improvement of energy efficiency and the diversification of energy sources to secure a supply of primary energy sources. Notable examples of that period were the Rational Energy Utilization Act and the Energy Efficiency Standards and Labelling Program, albeit that they failed to curtail growing energy consumption and greenhouse gas emissions (Kim and Jeong 1986: 57). To comply with the UNFCCC and thus reduce its emissions, the South Korean government devised a partnership programme with the country's industrial sector called Voluntary Agreements, which promised financial aid and tax advantages to 
those companies that managed to reach their self-imposed reduction targets (Lee and Oh 2002: 202). Apart from that, a law for the development of new and renewable energies was implemented in 2003, and a feed-in tariff has also come into force (Kim 2006: 73; Yoo 2008: 13). To achieve a certain degree of sustainability in the transportation sector, the Transportation System Rationalization Law of 1999 calls for the promotion of public transportation and hybrid and electric vehicles (Lee and Oh 2002: 204).

The Framework Act on Low Carbon, Green Growth, introduced on January 13, 2010, constitutes the first comprehensive body on climate protection in South Korea. Its function is described as:

The purpose of this Act is to promote the development of the national economy by laying down the foundation necessary for low carbon, green growth and by utilizing green technology and green industries as new engines for growth, so as to pursue the harmonized development of the economy and environment and to contribute to the improvement of the quality of life of every citizen and the take-off to a mature, top-class, advanced country that shall fulfill its responsibility in international society through the realization of a lowcarbon society (Ministry of Government Legislation 2010: 33).

The First Basic Plan of National Energy (2008-2030) was implemented at the same time. It defines energy policy measures in accordance with 'Low Carbon, Green Growth', focusing on sustainability. For the future, both a Renewable Portfolio Standard, an emission trading system, and a tax for carbon dioxide emissions are planned (Climate Connect 2011: 3; Jee 2008: paragraphs 1-16).

While South Korea, for the longest period after World War II, gave priority to economic development and the security of energy supply, there was a change in thinking after the Asian financial crisis in 1997. The real milestone on the way to becoming a pioneer in sustainable energy policies and climate protection is the Framework Act on Low Carbon, Green Growth. Despite its promising name and the government's wide-ranging promotion of it, environmental specialists and scientists are sceptical about the actual effect of the new energy policy. As Sun-Jin Yun noted, “"green' growth means simply the reduction of $\mathrm{CO}_{2}$ emissions and environmental pollutants" (Yun 2010: paragraph 9). Yun argues that the government redefines the meaning of 'green' to suit its interests, which remain economic growth. Moreover, initiatives like the Four Major Rivers Restauration project are even considered to be detrimental to environmental protection, and critics also point out that 24.5 percent of the government's budget for the Green Growth initiative has been used for the construction of railroads (Yun 2010: paragraphs 9-10). In light of this criticism, it remains to be seen whether South Korea's strategy will have a positive impact on its environment and energy policy. 


\section{South Korea's greenhouse gas emissions}

The rapid economic development that started in the 1960s caused not only a sharp rise in energy consumption but also greenhouse gas emissions. Between 1973 and 1990, emissions rose from about 100 million tons CDE to more than 280 million tons, 94.1 percent of it generated through energy consumption from all sectors. At 86 percent, carbon dioxide accounted for most of all emissions (Jung 1996: 258; UNFCCC 2011f: 1).

Whereas the industry sector's emissions remained constant despite the sharp increase in energy consumption, other sectors, above all the one constituted by heat and electricity production, followed by the housing and commercial sector and the transportation sector, saw their emissions rise (IEA 2006: 48; Jung 1996: 258).

In 1996, greenhouse gas emissions reached a provisional zenith, when they attained more than 400 million tons CDE. In the following year, because of the Asian financial crisis, they dropped to 360 million CDE, only to rise to a new high in 1999. Ever since, South Korea's greenhouse gas emissions have been increasing without a turning point in sight (International Energy Agency 2006: 48). By 2009, the country came ninth in the global ranking of carbon dioxide emissions by nation, with its growth rate between 1990 and 2005 far above the OECD average (Oh 2008: 485486). According to the second National Report of South Korea, compiled by the government for the UNFCCC, greenhouse gases - together with energy consumption-will continue to "rise by 70 percent above 2000 levels in 2020" unless effective measures to counteract this development are taken (Government of the Republic of Korea 2003: 70).

Because of its classification as a developing nation, the South Korean government has so far rejected binding reduction targets. At the national level, it began to work on measures to reduce emissions in 1998 with the publishing of the first National Action Plan for the UNFCCC. The government also started to encourage industry to accept Voluntary Agreements to achieve a reduction in its greenhouse gas emissions by improving energy efficiency and implementing new technologies. Critics argue that this step has failed to achieve its goal, as only 13.6 percent of the industrial sector has participated in the programme (Oh 2008: 488).

The first Basic Plan of National Energy brought a change in direction, as it provided medium and long-term reduction goals for the first time. By 2020, a reduction of 4 percent relative to 2005 should be reached (Cho 2009: paragraphs 1-2). To reach this target, the government has adopted a variety of measures: the expansion of nuclear power, improved energy efficiency in both the industrial and the transportation sectors, and the promotion of so-called low carbon green villages (Interna- 
tional Energy Agency 2006: 50; Climate Connect 2011:1-2). It remains to be seen, though, whether emissions will actually decrease in the future.

\section{South Korea's energy efficiency}

Compared to Japan, South Korea's energy intensity has been relatively high, despite various efforts to improve efficiency ever since the implementation of the Rational Energy Utilization Act in 1979. This law counts as one of the cornerstones of South Korea's energy policy, and has to date been revised in 2002, 2003 and 2008. The government body Korea Energy Management Corporation (KEMCO) is responsible for the realisation of the act (Vine, Rhee and Lee 2006: 1009). In 1983 and 1985, the government also published a Long-Term Energy Outlook and Strategy for the 2000s which, for the first time, dealt with long-term goals to reduce energy intensity. The main focus lay on industry and the housing and commercial sector, as they were responsible for 41.9 percent and 35.0 percent of the country's energy consumption respectively in 1983 (Kim and Jeong 1986: 66-67).

KEMCO implemented a variety of measures to raise energy efficiency in the 1990s: in 1992 the Energy Efficiency Standards and Labelling Program was launched, which provides manufacturers with 'Minimum Energy Performance Standards' for their products which they have to adhere to. In combination with this programme, the High Efficiency Energy-using Appliances Program seeks 'to enlarge the proportion of energy efficient appliances in the marketplace through authorization and financial support' (KEMCO 2011: 4).

Despite these measures, South Korean energy intensity rose even beyond its former high point of the year 1980 and stayed there until after the Asian financial crisis. A reverse trend commenced only after 1997. Starting in 2004, energy intensity sank 1.3 percent per year, yet is still around 50 percent higher than Japan's (IEA 2006: 59).

It also was not until 2004 that each sector got its own efficiency targets with the General Energy Conservation and Efficiency Improvement Plan, the aim of which is to reduce energy intensity by 8.6 percent compared to 2004 up until 2012 (Vine, Rhee and Lee 2006: 1109). With the implementation of the Framework Act on Low Carbon, Green Growth in 2010, the government vowed to adopt middle- and longterm efficiency targets (Ministry of Government Legislation 2010: 29). These are indispensable in reaching an efficiency rate similar to Japan's in the future.

\section{South Korea's use of energy sources}

While the share of anthracite coal in South Korea's primary energy sources continued to decrease steadily, the share of oil rose to 61.1 percent in 1980. In 1979, after the second oil crisis, the Korea Institute of Energy and Resources was founded, 
with the goal of solving the problems that energy policy faced and of developing alternative energy sources (Shin 1986: 40; Kim and Jeong 1986: 51). Natural gas was first imported in 1986. High import rates made it rise to 3.2 percent of all primary energy sources consumed in 1990 (Ministry of Knowledge Economy 2010: 11).

In the base year of the Kyoto Protocol, all fossil fuels combined accounted for 83.2 percent of all primary energy sources. Nuclear energy had a share of 14.2 percent, whereas renewable energies were mostly neglected (Kim 2006: 63). While government efforts made possible a reduction in the share of oil up to the $1990 \mathrm{~s}$, the government was in favour of other, similarly emission-intensive sources like coal and gas. The import rate also continued to grow, so that in 2003 Korea had a selfsufficiency rate of only 3 percent (Chung, Tohno and Shim 2009: 1902).

The government strives to reduce dependence on fossil fuels by expanding both nuclear and renewable energies, as stated in the First Basic Energy Plan of National Energy. At the same time, it also promotes the development of new technologies for the development of oil and gas. The goal is to raise the self-sufficiency rate to 40 percent by 2030 (Jee 2008: paragraph 20).

In 2006, renewable energies accounted for only 2.5 percent of all primary energy sources. As stated in 2008, the government wants to raise this rate to 11 percent in 2030 (Jee 2008: paragraph 9; Kim 2006: 73). To reach this goal, a 'Green Homes 1 Million' campaign has been launched, as well as the plan to implement a Renewable Portfolio Standard that binds suppliers to buying a certain amount of energy from renewable sources (Jee 2008: paragraph 17; Oh: 2008:489).

\section{The South Korean government's sufficiency strategies}

South Korea's sufficiency programmes are mainly consistent with Japan's. To save energy, the government concentrated on raising the energy efficiency of industry from the early 1970 s onwards. To reduce consumption by private housing, offices and factories, plans to improve insulation were implemented (Kim and Jeong 1986: 66-67).

In 2006, South Korea adopted Japan's Cool Biz campaign, which furnished savings of 300 billion won during the period from 5 June to 31 August 2006 (see the section above on 'The Japanese government's sufficiency strategies'; MOE ROK 2006: paragraph 3). Furthermore, the Energy-saving Office Equipment \& Home Electronics Program and the Standby Korea $1 \mathrm{~W}$ were implemented to reduce electricity consumption in the private and commercial sectors. The first motivates manufacturers to develop energy-saving home electronics and office equipment, which are then tagged with distinguishing labels, whereas the latter aims to reduce the stand-by consumption of 20 different electronic gadgets to one watt (Power Integrations 2011: paragraphs 2-4; UN 2011: 3). 
While the South Korean government mainly focuses on other measures to slow growing energy consumption and reduce emissions, the sufficiency strategies it has adopted can nevertheless be seen as successful.

\section{Conclusion}

The goal of this paper has been to analyse whether Japan and South Korea pursue a sustainable energy policy. The theoretical framework used to frame the concept of such an energy policy was taken from Holger Rogall's book Nachhaltige Ökonomie and his working paper 'Essentiales für eine nachhaltige Energie- und Klimaschutzpolitik'. As the first part of this paper has shown, a clear line between energy policy and other political sectors cannot be drawn. The former is especially connected with climate policy, notably on the international stage. Thus, the first two categories for analysis focus mostly on the fight against climate change, a fight that each country's government tries to conduct with energy policy measures.

Putting the categories of analysis from the section 'Definition of a sustainable energy policy' to use, the following results emerged: Japan, as a country with few natural resources usable for generating energy, became heavily dependent on the import of fossil fuels after World War II, which is why security of energy supply has played an important role in Japanese energy policy ever since. The government signed both the UNFCCC and the Kyoto Protocol. As an Annex I party, Japan accepted binding reduction targets: to cut greenhouse gas emissions by 6 percent between 2008 and 2012, relative to 1990. This stance also brought a break with the past, as the Japanese government joined the climate change debate comparatively late and rejected any responsibility up until the first half of the 1990, in order to preserve its economic growth. After implementing the Kyoto Protocol, however, the country established itself as one of the main proponents of international climate protection, advocating middle- and long-term reduction targets both nationally and internationally. Having accepted both of the two international treaties concerning climate change and followed a course to conform to them by adopting a variety of laws and measures domestically, Japanese energy policy can be seen as sustainable concerning the first two categories. Looking at actual developments in Japan since 1990, it can be said that the results are mixed. Despite vowing to reduce its greenhouse gases, emissions continued to rise. While there was a decline in emissions in 2008 and 2009, this can be attributed to the economic crisis and not to the measures taken by the government. To achieve permanent reductions, improvements in the transportation and housing sectors, as well as binding targets for industry will be necessary. When it comes to Japan's energy efficiency, the government's aims have been reached, making it the most energy-efficient country in the world. These aims, however, have not lessened dependency on imported fossil fuels. The share of oil 
has been reduced, but in favour of coal and gas. The importance nuclear energy played until 2011 and the minimal share of renewable energies are a hindrance to achieving a sustainable energy policy. Japan's main challenge for the years to come will be to craft a coherent energy policy, now that the catastrophe in Fukushima has made the old one obsolete. The public's opinion of nuclear power is now largely negative, with demonstrators filling the streets and surveys showing that about 70 percent of Japan's population favours exiting nuclear power (Sieg 2012: paragraph 14). It will not be easy for the government to find a coherent strategy, though, as turning off all reactors in 2011 made imports of fossil fuels rise rapidly, with the consequence that the country had to spend about US\$34 billion more on imports in 2012 than only a year before (Sieg 2012: paragraph 11). Thus, the main challenge for the government élite, on which they have yet to decide, will be to find a compromise between supporting renewable energy sources and exiting nuclear power at a time in the future when such a step will be neither too costly nor detrimental to Japan's climate protection efforts. Analysing Japan's sufficiency strategies, however, has revealed that while such measures cannot be seen as vital for the country's energy policy, the strategies that have been implemented have been highly successful.

The analysis of South Korea's energy policy has shown that the country's energy policy is not fully in accordance with international operation targets and legal norms. Similarly to Japan, South Korea is highly dependent on the import of fossil fuels and thus focuses on security of energy supply. Categorised as a developing nation, the government has signed both the UNFCCC and the Kyoto Protocol, but has rejected binding reduction targets so far. South Korea only started turning towards an energy policy in accordance with international treaties and legal norms in 2010, when the Framework Act on Low Carbon, Green Growth was implemented. Because of this late revision of opinion, actual developments since 1990 look rather bleak. Greenhouse gas emissions, still relatively low in 1990, rose quickly up to 2007, despite a temporary decline caused by the Asian financial crisis. According to analysts, they will rise even further, unless the country adopts reduction measures soon. Energy efficiency, too, is high compared to countries like Japan, with the energy-intensive industrial sector mainly responsible. A convergence will be achieved only slowly. Like Japan, South Korea is heavily dependent on imported fossil fuels, which constitute the majority of all primary energy sources consumed. While its oil consumption has fallen, the shares of natural gas and coal have instead risen. To improve its selfsufficiency rate, the government has focused on expanding nuclear energy, whereas renewable energies have been largely ignored, a factor hindering the achievement of a sustainable energy policy. When it comes to sufficiency strategies, however, similar results to Japan's could be achieved, albeit such measures play only a small role in the overall energy policy. 
In summary, Japan's energy policy can be seen as sustainable to a certain degree. The foundation has been set and the government is committed to reach its goals. There is still a lot of catching-up to do when it comes to the use of energy sources and the expansion of renewable energies. South Korea's energy policy, on the other hand, cannot be seen as sustainable yet. There is a need for change in nearly all categories. Since 2008, the government has embarked on a way to more sustainability. It now depends on the implementation of measures and ideas to reach a higher degree of sustainability in the future. 


\section{REFERENCES}

Akahoshi, Yasushi. "Energy Efficiency and Conservation Policies and Measures in Japan.” In Energy Efficiency in Japan, edited by Agung Wicaksono. Singapore: Institute of Southeast Asian Studies, 2008, pp. 21-87

APEC Energy Working Group. "EWG38 Notable Energy Developments - Japan”. 2009, APEC Energy Working Group website, http://www.ewg.apec.org/documents/SummaryRecordEWG38.pdf, accessed June 2011

Asuka-Zhang, Shouchuan. "Development Assistance and Japan's Climate Change Diplomacy: Priorities and Future Options.” In Global Warming and East Asia, edited by Paul G. Harris. London and New York: Routledge, 2003, pp. 152-166

BMWFJ (Bundesministerium für Wirtschaft, Familie und Jugend). "Energieeffizienz." 2011, http://www.bmwfj.gv.at/ENERGIEUNDBERGBAU/ENERGIEEFFIZIENZ/Seiten/default.asp $\mathrm{x}$, accessed June 2011

Böhringer, Christoph, and Carsten Vogt. "Economic and Environmental Impacts of the Kyoto Protocol.” In The Canadian Journal of Economics, 36/2, 2003, pp. 475-494

Cho, Mee-young. "South Korea Targets 2020 Emissions at 30 Percent below Forecast." Reuters, November 17, 2009, http://www.reuters.com/article/2009/11/17/us-korea-emissionidUSTRE5AG0DN20091117, accessed June 2011

Choi, Kyoung-Sik. "Climate Change Measures and Kyoto Mechanism, Ministry of Environment, Korea.” 2009, http://eng.me.go.kr/board.do?method=list\&bbsCode=res_mat policy\&categoryCode $=04$, accessed June 2011

Chung, Whan-Sam, Susumo Tohno, and Sang Yui Shim. "An Estimation of Energy and GHG Emission Intensity Caused by Energy Consumption in Korea: An Energy Approach.” In Applied Energy, 86, 2009, pp. 1902-1914

Climate Connect. "Fact Sheet: South Korea Climate Change Policies." 2011, Climate Connect Ltd website, http://www.climate-conect.co.uk/Home/sites/default/files/Fact\%20Sheet\% 20South\%20Korea\%20Climate\%20Policy.pdf, accessed June 2011

Covering Copenhagen. "Country Profiles: Japan.” 2011, http://coveringcopenhagen.com/ countries/japan/, accessed July 2011

Duffield, John S., and Brian Woodall. “Japan's New Basic Energy Plan.” In Energy Policy, 39/6, 2011, pp. 3741-3749

ECCJ (The Energy Conservation Centre, Japan). "Chronicles of Energy Conservation Laws." 2011, http://www.asiaeec-col.eccj.or.jp/chronicle/index.html, accessed June 2011

Ferrari, Claudio G. "Third Party Financing: New Financial Tools for Energy Efficiency - An International Perspective.” In Sustainable Energy Production and Consumption, edited by Frano Barbir and Sergio Ulgiati. Dordrecht: Springer, 2008, pp. 171-183

Government of the Republic of Korea. "Second National Communication of the Republic of Korea Under the United Nations Framework Convention on Climate Change.” 2003, United Nations Framework Convention on Climate Change website, http://unfccc.int/resource/docs/ natc/kornc02.pdf, accessed June 2011

Green Car Congress. "Global CO2 Emissions up 38\% Since 1992.” 2008, http://www.greencarcongress.com/2008/09/global-co2-emis.html, accessed June 2011

Griffin, James M. A Smart Energy Policy. New Haven and London: Yale University Press, 2009

Grubb, Michael, Christiaan Vrolijk, and Duncan Brack. The Kyoto Protocol: A Guide and Assessment. London: Royal Institute of International Affairs, 1999

Hagem, Cathrine et al. "Enforcing the Kyoto Protocol: Sanctions and Strategic Behaviour." In Energy Policy, 33, 2005, pp.2112-2122 
IEA (International Energy Agency). "CO2 Emissions from Fuel Combustion - Highlights.” 2010a, International Energy Agency website, http://www.iea.org/co2highlights/ co2highlights.pdf, accessed May 2011

IEA. "Energy Policies of IEA Countries - The Republic of Korea 2006 Review.” 2006, International Energy Agency website, http://www.iea.org/textbase/nppdf/free/2006/korea2006.pdf, accessed June 2011

IEA. “CO2 Emissions by Region.” 2010a, International Energy Agency website, http://www.iea.org/textbase/nppdf/free/2010/key_stats_2010.pdf, accessed May 2011

IEA. "Share of Total Primary Energy Supply in 2008 - Japan." 2010b, International Energy Agency website, http://www.iea.org/stats/pdf_graphs/JPTPESPI.pdf, accessed June 2011

IEA. “Act Concerning the Rational Use of Energy (2002 Revised Energy Conservation Act).“ 2010c, International Energy Agency website, http://www.iea.org/textbase/pm/?mode=pm \&id=911\&action=detail, accessed Juni 2011

IPCC (Intergovernmental Panel on Climate Change). "Development, Sustainability and Equity." 2000, Intergovernmental Panel on Climate Change website, http://www.ipcc.ch/pdf/supporting-material/des-2nd-ipcc-expert-meeting.pdf, accessed June 2011

IPCC. “IPCC Technical Paper III.” 1997, Intergovernmental Panel on Climate Change website, http://www.ipcc.ch/pdf/technical-papers/paper-III-en.pdf, accessed June 2011

IPCC. "History." 2011, Intergovernmental Panel on Climate Change website, http://www.ipcc.ch/organization/organization_history.shtml, accessed June 2011

Japan Environmental Quarterly. "News from the Environment Agency.” In Japan Environmental Quarterly, 3/4, 1998, pp.1-8

Jee, Mark. "The First Basic Plan on National Energy (2008-2030) of Korea.” 2008, http://www.displaybank.com/eng/info/show.php?c_id=3539, accessed June 2011

Jung, Tae Yong, and Jae Eun Ahn. "Domestic Policies for Climate Change: Republic of Korea." 2010, Crawford School of Economics and Government website, www.crawford.anu.edu.au/accpforum/pdf/ppp/8_Jung.pdf, accessed June 2011

Jung, Yonghun. "Scenarios of Future Energy Demand and Carbon Dioxide Emissions in the Republic of Korea." In Ambio, 25/4, 1996, pp. 258-262

Kameyama, Yasuko. "Climate Change as Japanese Foreign Policy: From Reactive to Proactive." In Global Warming and East Asia, edited by Paul G. Harris. London and New York: Routledge, 2003, pp. 135-151

KEMCO. "Energy Efficiency Programs in Korea.” 2011, KEMCO website, http://www.kemco.or.kr/web/kcms/bord/bord_FD.asp?f=4119, accessed June 2011

Kikkawa, Takeo. "Entrepreneurial Way to Cool the Earth." In Hitotsubashi Journal of Commerce and Management, 44, 2010, pp. 1-11

Kiko Network. "Fact sheet of the Keidanren Voluntary Action Plan." 2007, http://www.kikonet.org/english/publication/archive/keidanren-vap.pdf, accessed June 2011

Kim, Bong-ki. “Die Energiepolitik Südkorea.” In Die Energiepolitik Ostasiens, edited by Xuewu $\mathrm{Gu}$ and Kristin Kupfer. Frankfurt am Main: Campus Verlag, 2006, pp. 61-84

Kim, Chan-woo. "Negotiations on Climate Change: Debates on Commitments of Developing Countries and Possible Responses." In East Asian Review, 14/1, 2002, pp. 45-60

Kim, Hwang Joe, and Kap-young Jeong. "Development of Alternative Energy Sources and Energy Conservation in Japan and Korea." In Energy Policy in Korea and Japan, edited by Dalchoong Kim and Euisonn Shin. Seoul: Yonsei University Press, 1986, pp. 47-72 
Kodaka, Atsushi. “Japan's Top Runner Program: The Race to the Top.” 2008, Eceee website, http://www.eceee.org/eceee_events/product_efficiency_08/programme_presentations/Kodaka_ TopRunnerProgram.pdf, accessed June 2011

Krupp, Helmar. "Japanische Energiepolitik.” In Energiepolitik, edited by Hans Günter Brauch. Berlin: Springer, 1997, pp. 243-252

Lau, Lee Chung et al. "A Comparative Study on the Energy Policies in Japan and Malaysia in Fulfilling Their Nations Obligations towards the Kyoto Protocol.” In Energy Policy, 37, 2009, pp. 4771-4778

Laumanss, Ulrich. "Determinanten der Energiepolitik.” In Grundlagen der Energiepolitik, edited by Danyel Reiche. Frankfurt am Main: Peter Lang, 2005, pp. 279-289

Lee, Hoesung, and Jin-Gyo Oh. "Mitigation Initiatives: Korea’s Experiences.” In Climate Policy, 2, 2002, pp. 197-209

Lexikon der Nachhaltigkeit. "Weltklimakonferenzen in Genf, 1979-2009.” 2011, http://www.nachhaltigkeit.info/artikel/weltklimakonferenz_genf_1979_689.htm, accessed June 2011

Lovett, Jon C. “1997 Kyoto Protocol.” In Journal of African Law, 49/1, 2005, pp. 94-96

METI (Ministry of Economy, Trade and Industry). "New National Energy Strategy." 2006, Ministry of Trade and Industry website,

http://www.enecho.meti.go.jp/english/report/newnationalenergystrategy2006.pdf, accessed June 2011

METI. "The Strategic Energy Plan of Japan.” 2010a, Ministry of Trade and Industry website, http://www.meti.go.jp/english /press/data/pdf/20100618_08a.pdf, accessed June 2011

METI. "Establishment of the Strategic Energy Plan of Japan." 2010b, Ministry of Trade and Industry website, http://www.meti.go.jp/english/press/data/20100618_08.html, accessed June 2011

Ministry of Government Legislation. "Framework Act on Low Carbon, Green Growth.” 2010, Ministry of Government Legislation website,

http://www.greengrowth.org/download/Framework\%20Act\%20on\%20Low\%20Carbon\%20Gr een\%20Growth\%202010.pdf, accessed June 2011

MKE (Ministry of Knowledge Economy). "Yearbook of Energy Statistics 2010.” 2010, Ministry of Knowledge Economy (Republic of Korea) website, http://www.keei.re.kr/keei/ download/YES2010.pdf, accessed June 2011

MKE. "Energy Policies." 2011, Ministry of Knowledge Economy (Republic of Korea) website, http://www.mke.go.kr/language/eng/policy/Epolicies_04.jsp, accessed June 2011

MOE Japan (Ministry of the Environment, Japan). "Result of 'Cool Biz' Campaign.” 2005, Ministry of the Environment (Japan) website, http://www.env.go.jp/en/press/2005/1028a.html, accessed June 2011

MOE Japan. "The Kyoto Protocol Target Achievement Plan.” 2008, Ministry of the Environment (Japan) website, http://www.env.go.jp/en/earth /cc/kptap.pdf, accessed July 2011

MOE Japan. “About Us.” 2011, Ministry of the Environment (Japan) website, http://www.env.go.jp/en/aboutus/pamph/html/index.html, accessed June 2011.

MOE ROK (Ministry of Environment, ROK). "Let's Cut CO2 Emission! Lose the Tie and Keep the Summer and the Earth Cool." 2006, http://eng.me.go.kr/board.do?method=view\&bbsCode=new_news\&docSeq=7859, accessed June 2011

MOE ROK. "Overview.” 2011, http://eng.me.go.kr/content.do? method=moveContent\&menuCode=pol_gre_overview, accessed June 2011 
MOFA (Ministry of Foreign Affairs). "Statement Made by the Delegation of Japan." 2003, http://www.mofa.go.jp/policy/ environment/warm/cop/cop9_1.html, accessed June 2011

MOFA. "Organization and Function.” 2009, http://www.mofa.go.jp/about/hq/org.html, accessed June 2011

MOFA. “Announcement: Quantified Economy-wide Emissions Targets for 2020.” 2010, Ministry of Foreign Affairs website, http://www.mofa.go.jp/announce/announce/2010/1/PDF/ 012601e.pdf, accessed June 2011

MOFAT (Ministry of Foreign Affairs and Trade). "History." 2011a, http://www.mofat.go.kr/english/ministry/organization/history/index2.jsp, accessed June 2011

MOFAT. "Key Diplomatic Task." 2011b, http://www.mofat.go.kr/english/political/tasks/index.jsp, accessed June 2011

Morse, Ronald A. "Introduction: Japan's Energy Policies and Options.” In The Politics of Japan's Energy Strategy, edited by Ronald A. Morse. Berkley CA: Institute of East Asian Studies, University of California, 1981, pp. 1-14

National Institute for Environmental Studies. “Japan's National Greenhouse Gas Emissions in Fiscal Year 2008 (The Final Figures).” 2010a, Institute for Environmental Studies website, http://www.nies.go.jp/whatsnew/2010/20100415/gaiyo-e.pdf, accessed June 2011

National Institute for Environmental Studies. “Japan's National Greenhouse Gas Emissions in Fiscal Year 2009 (The Preliminary Figures).” 2010b, National Institute for Environmental Studies website, http://www.nies.go.jp/whatsnew/2010/20101227/gaiyo-e.pdf, accessed June 2011

New and Renewable Energy Division, Agency for Natural Resources and Energy. "METI"s Initivative on Algal Biofuels." 2010, http://www.sakura.cc.tsukuba.ac.jp/ eeeforum/AOAIS/ slides/2-3ADP486C.pdf, accessed June 2011

Nishimura, Makoto, and Ram Giri. "Energy Efficiency and New Technology: Challenges and Problems on Exporting Japanese Energy Saving Technologies." In Energy Efficiency in Japan, edited by Agung Wicaksono. Singapore: Institute of Southeast Asian Studies, 2008, pp. 1-19

Oh, Ilyoung. "Status of Climate Change Policies in South Korea." In Springer Proceedings in Physics, 124/4, 2008, pp.485-493

Ohkuni, Kotaro. "Standby Power in Japan”, 2008, International Energy Agency website, http://www.iea.org/work/2008/indiastandby/OOhuni_ECCJ.pdf, accessed June 2011

Power Integrations. "Energy Saving Office Equipment and Home Electronics Program.” 2011, http://www.powerint.com/green-room/regulations-agency/korea-energy, accessed June 2011

Presidential Committee on Green Growth. "National Strategy." 2011, http://www.greengrowth.go.kr/english/en_policy/en_strategy/en_strategy.cms, accessed June 2011

Prime Minister of Japan and His Cabinet. "Guideline for Measures to Prevent Global Warming (Summary).” 2002, http://www.kantei.go.jp/foreign/policy/ondanka/020319summary_e.html, accessed June 2011

Prime Minister of Japan and His Cabinet. "Invitation to 'Cool Earth 50' - 3 Proposals, 3 Principles.” 2007, http://www.kantei.go.jp/foreign/abespeech/2007/05/24speech_e.html, accessed May 2011

Reiche, Danyel. “Geschichte der Energie.” In Grundlagen der Energiepolitik, edited by Danyel Reiche. Frankfurt am Main: Peter Lang, 2005, pp. 11-36

Rogall, Holger. Nachhaltige Ökonomie. Marburg: Metropolis-Verlag, 2009

Rogall, Holger. "Essentiales für eine nachhaltige Energie- und Klimaschutzpolitik." Working Paper, No. 5/2008, IMB Institute of Management Berlin, 2008 
Shiel, Patrick, Nick Jeffer, and Mark Dyar. Energy Conservation Measures in Japan. Dublin: Trinity College Dublin, 2011

Shin, Euisoon. "Energy Supply Policies in Korea and Japan." In Energy Policies in Korea and Japan, edited by Dalchoon Kim und Euisoon Shin. Seoul: Yonsei University Press, 1986, pp. $1-45$

Sieg, Linda. “Reactor Restarts, But Japan's Energy Policy in Flux.” 2012, http://business.financialpost.com/2012/07/04/reactor-restarts-but-japans-energy-policy-influx/, accessed January 2013

Spiegel Online. "Treibhausgas-Ausstoß steigt schneller als je zuvor.” May 30, 2011, http://www.spiegel.de/wissenschaft/natur/0,1518,765602,00.html, accessed June 2011

Stavins, Robert. "Opportunities and Ironies: Climate Policy in Tokyo, Seoul, Brussels, and Washington." 2010, http://belfercenter.ksg.harvard.edu/analysis/stavins/?p=568, accessed June 2011

Töpfer, Klaus. "Vorwort von Klaus Töpfer.” In Grundlagen der Energiepolitik, edited by Danyel Reiche. Frankfurt am Main: Peter Lang, 2005, pp. 5-6

Umbach, Frank. "Die Energiepolitik Japans." In Die Energiepolitik Ostasiens, edited by Xuewu $\mathrm{Gu}$ and Kristin Kupfer. Frankfurt am Main: Campus Verlag, 2006, pp. 41-60

Umweltbundesamt. “Atmosphärische CO2-Konzentration.” 2011, Umweltbundesamt website, http://www.umweltbundesamt-daten-zur-umwelt.de/umweltdaten/public/ theme.do?nodeIdent=2844, accessed June 2011

United Nations. "United Nations Framework Convention on Climate Change.” 1992a, United Nations website, http://unfccc.int/resource/docs/convkp/conveng.pdf, accessed June 2011

UN (United Nations). “Agenda 21.” 1992b, United Nations website, http://www.un.org/Depts/german/conf/agenda21/agenda_21.pdf, accessed June 2011

UN. "Kyoto Protocol and the UN Climate Change Secretariat A Global Freamework [sic] to Tackle Climate Change." 2007, United Nations Joint Press Kit for Bali Climate Change Conference website, http://www.un.org/climatechange/pdfs/bali/unfcc-bali07-2.pdf, accessed June 2011

UN. "Republic of Korea - Standby Power 1W Program.” 2011, United Nations website, http://www.un.org/esa/sustdev/csd/casestudies/e3_5_korea.pdf, accessed June 2011

UNFCCC (United Nations Framework Convention on Climate Change). "Fact Sheet: An Introduction to the United Nations Framework Convention on Climate Change (UNFCCC) and its Kyoto Protocol.” 2011a, United Nations Framework Convention on Climate Change website, http://unfccc.int/press/fact_sheets /items/4978.php, accessed June 2011

UNFCCC. "Kyoto Protocol." 2011b, United Nations Framework Convention on Climate Change website, http://unfecc.int/kyoto_protocol/items/2830.php, accessed June 2011

UNFCCC. "An Introduction to the Kyoto Protocol Compliance Mechanism.” 2011c, United Nations Framework Convention on Climate Change website, http://unfccc.int/kyoto_protocol/ compliance/items/3024.php, accessed June 2011

UNFCCC. "Summary of GHG Emissions for Japan." 2011d, United Nations Framework Convention on Climate Change website, http://unfccc.int/files/ghg_emissions_data/application/pdf/ jpn_ghg_profile.pdf, accessed June 2011

UNFCCC. "Status of Ratification of the Convention." 2011e, United Nations Framework Convention on Climate Change website, http://unfccc.int/essential_background/convention/status_of_ratification/items/2631.php, accessed June 2011

UNFCCC. "Emissions Summary for Republic of Korea." 2011f, United Nations Framework Convention on Climate Change website, http://unfccc.int/files/ghg_data/ghg_data_unfccc/ ghg_profiles/application/pdf/kor_ghg_profile.pdf, accessed June 2011 
Vine, Edward, C.H. Rhee, and K.D. Lee. "Measurement and Evaluation of Energy Efficiency Programs: California and South Korea.” In Energy, 31, 2006, pp. 1100-1113

Voß, Alfred. "Leitbilder und Wege einer umwelt- und klimaverträglichen Energieversorgung." In Energiepolitik, edited by Hans Günter Brauch. Berlin: Springer, 1997, pp. 59-74

Voß, Alfred, Ulrich Fahl, and Peter Schaumann. "Strategien zur Minderung energiebedingter Treibhausgasemissionen - Die Rolle der Kernenergie und des Erdgases.” In Energiepolitik, edited by Hans Günter Brauch. Berlin: Springer, 1997, pp. 389-400

Weizsäcker, Ernst Ulrich von. “Geleitwort.” In Nachhaltige Ökonomie, edited by Holger Rogall. Marburg: Metropolis-Verlag, 2009, pp. 19-26

Winterfeld, Uta von. "Keine Nachhaltigkeit ohne Suffizienz.” In Vorgänge, 3, 2007, pp. 46-54

World Energy Council. Energy Efficiency Policies around the World: Review and Evaluation. London: World Energy Council, 2008

World Nuclear Association. "Nuclear Power in Japan.” 2011, World Nuclear Association website, http://www.world-nuclear.org/info/inf79.html, accessed June 2011

Woyke, Wichard, ed. Handwörterbuch Internationale Politik. Opladen: Verlag Barbara Budrich, 2008

Yoo, SeungJick. "Climate Change Policies in Korea." 2008, Economic and Social Research Institute, Cabinet Office, Government of Japan website, http://www.esri.go.jp/jp/workshop/080225/02_country1_Korea.pdf, accessed June 2011

Yun, Sun-Jin. "Not So Green: A Critique of South Korea's Growth Strategy.” 2010, http://www.globalasia.org/print.php?c=e297, accessed January 2012 


\section{GLOSSARY}

Abe Shinzō

Fukushima daiichi genshiryokuhatsuden shojiko

Nihon keizaidantairengōkai Kyōto
安倍晋三

福島第一原子力発電 所事故

日本経済団体連合会 京都 ninetieth prime minister of Japan, in office from 26 September 2006 to 26 September 2007

Fukushima Daiichi nuclear disaster

Japanese Business Federation Kyōto, the former imperial capital of Japan, was the location for the third COP, when the Kyoto Protocol was passed 